\title{
Radar Observations of Arctic Bird Migration in the Beringia Region A. HEDENSTRÖM, ${ }^{1}$ T. ALERSTAM,${ }^{2}$ J. BÄCKMAN,${ }^{2}$ G.A. GUDMUNDSSON,${ }^{3}$ S. HENNINGSSON,${ }^{2}$ H. KARLSSON,${ }^{2}$ M. ROSÉN ${ }^{2}$ and R. STRANDBERG ${ }^{2}$
}

(Received 17 August 2007; accepted in revised form 17 April 2008)

\begin{abstract}
Bird migration was recorded by tracking radar and visual observations in the Beringia region. The data were subdivided into seven areas extending from north of Wrangel Island southeastward toward the Bering Strait and then northwestward off the coast of Alaska to Point Barrow. The studies, which took place during a ship-based expedition between 30 July and 19 August 2005, recorded a total of 557 tracks (average duration 120 seconds) of bird flocks or individuals on post-breeding migration. The dominant eastward-flying flocks were likely composed of shorebirds on their way from breeding areas in central or eastern Siberia to intermediate stopovers and final destinations in North and South America. The courses were more southerly into the Bering Strait, possibly because of topographical influence. At two areas, the Chukchi Sea and Koluchinskaya Bay, there was also a westward component of migrants. At the Chukchi Sea these were almost certainly passerine birds migrating from Alaska to wintering areas in Asia and Africa, while at Koluchinskaya Bay, king eiders on molt migration could represent an important part of the westward component. The overall mean altitude of flights was $1157 \mathrm{~m}$, and flight altitude was positively correlated with latitude. The mean ground speed was $15.9 \mathrm{~m} / \mathrm{s}$ and the mean airspeed was $14.1 \mathrm{~m} / \mathrm{s}$, indicating that on average the birds were experiencing a small tail wind component. The airspeed was a function of the tail wind component and the vertical speed; altitude and the side wind component did not contribute significantly to variation in airspeed in this data set. Comparing these results with similar data obtained from Siberia and Canada, we concluded that Beringia is a migration hotspot where intense bird migration crosses between Asia and Alaska in both directions.
\end{abstract}

Key words: Arctic birds, bird flight, migration, Beringia, flight altitude, flight speed, orientation, great circle, radar

RÉSUMÉ. La migration d'oiseaux a été enregistrée au moyen de radars de poursuite et d'observations visuelles dans la région de Béringie. Les données ont été sous-divisées en sept zones, allant du nord de l'île Wrangel vers le sud-est en direction du détroit de Béring, puis vers le nord-ouest, au large de la côte de l'Alaska jusqu'à la pointe Barrow. Les études ont été effectuées dans le cadre d'une expédition en bateau réalisée entre le 30 juillet et le 19 août 2005. Elles ont permis de répertorier un total de 557 pistes (d'une durée moyenne de 120 secondes) de volées d'oiseaux ou d'oiseaux individuels en migration de post-reproduction. Les volées dominantes en direction de l'est étaient probablement composées d'oiseaux de rivage venant de leurs aires de reproduction du centre ou de l'est de la Sibérie en route vers des escales intermédiaires et des destinations finales situées en Amérique du Nord et en Amérique du Sud. Dans le détroit de Béring, les parcours se trouvaient plus au sud, ce qui était peut-être attribuable à l'influence de la topographie. Dans deux zones, en mer des Tchouktches et dans la baie Koluchinskaya, il y avait aussi une composante de migrants en direction de l'ouest. À la mer des Tchouktches, il y avait presque certainement des passériformes en migration de l'Alaska vers des aires d'hivernage en Asie et en Afrique, tandis que dans la baie de Koluchinskaya, des eiders à tête grise en migration de mue auraient pu représenter une partie importante de la composante en direction de l'ouest. L'altitude moyenne générale des vols était de $1157 \mathrm{~m}$, et l'altitude des vols était positivement corrélée à la latitude. La vitesse moyenne au sol atteignait $15,9 \mathrm{~m} / \mathrm{s}$ et la vitesse aérodynamique moyenne s'établissait à 14,1 $\mathrm{m} / \mathrm{s}$, ce qui indique qu'en moyenne, les oiseaux subissaient un faible vent arrière. La vitesse aérodynamique était une fonction de la composante du vent arrière et de la vitesse verticale; la composante de l'altitude et du vent latéral n'a pas contribué considérablement à la variation de la vitesse aérodynamique dans cet ensemble de données. Après avoir comparé ces résultats à des données semblables prélevées en Sibérie et au Canada, nous en avons conclu que la Béringie est un point chaud de migration où des migrations intenses d'oiseaux traversent entre l'Asie et l'Alaska dans les deux sens.

Mots clés : oiseaux de l'Arctique, vol d'oiseau, migration, Béringie, altitude de vol, vitesse de vol, orientation, grand cercle, radar

Traduit pour la revue Arctic par Nicole Giguère.

\footnotetext{
${ }^{1}$ Department of Theoretical Ecology, Lund University, Ecology Building, SE-223 62 Lund, Sweden; corresponding author: anders.hedenstrom@teorekol.lu.se

${ }^{2}$ Department of Animal Ecology, Lund University, Ecology Building, SE-223 62 Lund, Sweden

${ }^{3}$ Icelandic Institute of Natural History, PO Box 5320, IS-125 Reykjavik, Iceland

(C) The Arctic Institute of North America
} 


\section{INTRODUCTION}

The cold winters prevent year-round residency of most birds in the Arctic, but the high productivity during summer attracts large numbers of migratory birds that come there to breed. Migratory journeys of Arctic-breeding birds are often impressive, commonly involving movements between High Arctic tundras and wintering areas in the Southern Hemisphere.

Research on bird migration in the Arctic is still incomplete, partly because of the costs and practical difficulties of getting there with appropriate equipment. Previous landbased radar studies have been carried out in Alaska (Flock, 1972, 1973), along the Yukon coast of the Beaufort Sea (Richardson and Johnson, 1981; Johnson and Richardson, 1982), and in Greenland (Alerstam et al., 1986). A different approach was taken during the summer of 1994, when a tracking radar unit was placed on a ship that sailed along the northern coast of Siberia (Alerstam and Gudmundsson, 1999a). This approach was later followed up in the central Arctic Ocean near the geographic North Pole (Gudmundsson and Alerstam, 1998) and along the Northwest Passage in Canada (Gudmundsson et al., 2002). However, a gap in the coverage by radar studies around the Arctic Circle remained in the Beringia region. This study aimed to fill that gap and provide a picture of the migratory traffic of birds in the region.

The Swedish botanist Eric Hultén (Hultén, 1937) first introduced the concept of Beringia as a unique biogeographic region. From a Quaternary geological perspective, Beringia is usually defined as the region between the Mackenzie River (Canada) to the east and the Kolyma (sometimes the Lena) River to the west, including the entire Kamchatka Peninsula to the south (summarized in Hoffecker and Elias, 2003). Beringia was originally defined on the basis of its characteristic flora, but it also contains unique mammalian species. A characteristic feature of Beringia is that it remained essentially ice-free during the late Pleistocene glaciations and hence has provided refuges for many plant and animal species during the last glacial period. A broad land bridge between Asia and North America covered the present Bering Strait during the last glaciation: more than $1000 \mathrm{~km}$ of tundra separated the Bering Sea from the Arctic Ocean, allowing dispersal of organisms between the continents. From a diversity perspective, Beringia is comparatively rich in species (e.g., Henningsson and Alerstam, 2005). Many bird species occur as breeders on both sides of the Bering Strait. Some are of Eurasian origin but have an Alaskan breeding contingent. These include the northern wheatear (Oenanthe oenanthe), with wintering areas in Africa, and the arctic warbler (Phylloscopus borealis), which winters in southern SE Asia. A variety of other Arctic breeders, such as the western sandpiper (Calidris mauri) and the pectoral sandpiper (C. melanotos) (Morrison, 1984; Wilson, 1994; Holmes and Pitelka, 1998), range across the American and Siberian coasts but migrate to wintering areas in the New World.
In this study, we placed two tracking radar stations on board the Swedish icebreaker Oden in order to record postbreeding migratory movements of birds in the Beringia region. The approach was similar to that used during previous expeditions in the Russian and Canadian Arctic (Alerstam and Gudmundsson, 1999a; Gudmundsson et al., 2002), allowing comparison among the different regions. This paper reports our findings about bird migration in Beringia, with an emphasis on describing the occurrence and the directions, altitudes, and speeds of migrating birds. We also emphasize the complicated and interesting picture formed by patterns of bird migration between Asia and America, suggesting that Beringia is a migration hot spot. In addition to the present general account, further in-depth analyses of the great circle migration in passerines and other Arctic birds are presented elsewhere (Alerstam et al., 2007, 2008).

\section{STUDY AREAS AND METHODS}

Radar data were collected from the Swedish state icebreaker Oden during the "Beringia 2005" expedition (Rickberg, 2006). The expedition was divided into three parts: (1) transportation from Sweden via the Northwest Passage to the Bering Strait, (2) circuitous movements within Beringia with rotation at Barrow, Alaska (Fig. 1), and (3) the return journey from Alaska to Sweden via the geographic North Pole and Svalbard. Bird observers were present during all three parts, two people during parts 1 and 3 , and four during part 2. Migrating birds were recorded according to standardized protocols during the first and third parts of the expedition. During the second (Beringian) part, the emphasis was on radar observations, although visual observations were carried out as well. Radar observations were performed when Oden was anchored at field sites, but also when Oden was moving, except during passage through ice, when vibrations prevented radar operation (see Fig. 1). Sea ice limited radar observation mainly to the Beringia part of the expedition. For purposes of analysis, the radar material was subdivided into seven areas (A-G, Fig. 1), but for many analyses the total combined data set was used.

Observations about migrating and stationary (staging or flocking) birds were also made at five different land locations (1-5, Fig. 1). The duration of these visits was brief $(1-3$ days), except at field site 2 (Mekigney Bay), where a field camp was established for one week. Additional information about bird movements or gatherings was also obtained from other ornithologists participating in the expedition. The purpose of the field observations was to supplement radar data and possibly identify the sources of the radar echoes, whose species was observed only in very few cases.

Two tracking radars (PV882 and PV301; $3 \mathrm{~cm}$ wavelength, $200 \mathrm{~kW}$ peak power, 0.25/1.0 $\mu$ s [0.5 $\mu$ s for PV301] pulse duration, and $1.5^{\circ}$ [1.65 for PV301] nominal pencil beam width) were placed $19 \mathrm{~m}$ above sea level, one on each side of the rear end of the fourth deck of Oden. This deployment gave an approximately $270^{\circ}$ sector in which birds 


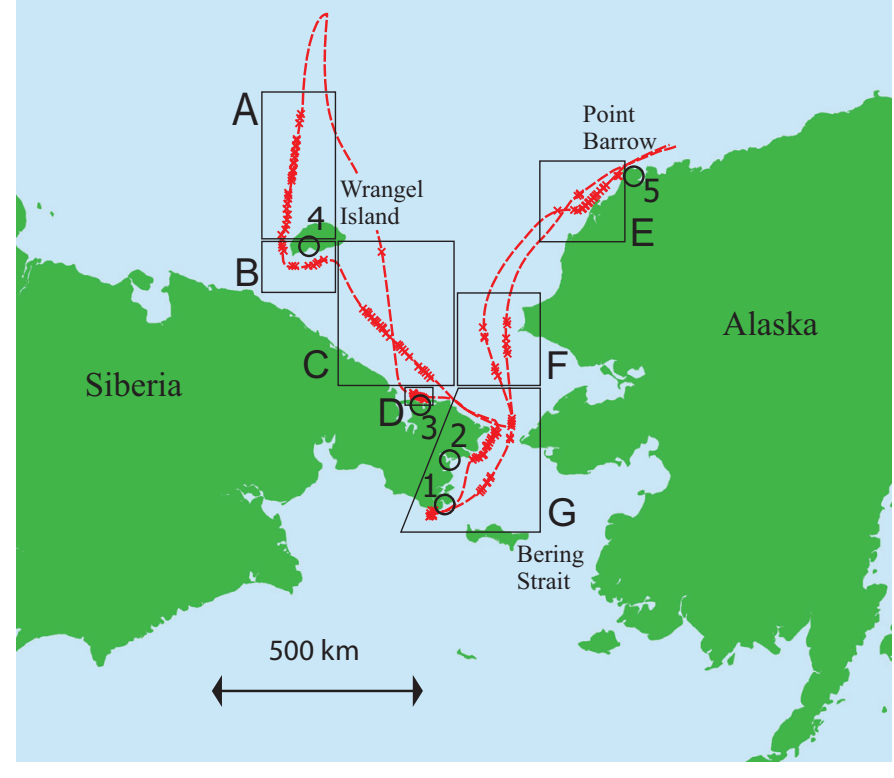

FIG. 1. Map of Beringia showing the cruise of the icebreaker Oden (broken line) and records of radar bird trackings (x). The quadrilaterals define the seven areas $(A-G)$ used for analyses of directions of migrating birds: (A) North of Wrangel Island, (B) South of Wrangel Island, (C) Chukchi Sea, (D) off Koluchinskaya Bay, (E) off the coast of Northwest Alaska, (F) off the coast of West Alaska, and (G) Bering Strait. Open circles with numbers show the land sites visited for field observations of migrating and resting birds: (1) Providenya, (2) Mekigney Bay, (3) Koluchinskaya, (4) Wrangel Island, (5) Barrow.

could be tracked. Both radars could be operated simultaneously, although often only one was operational. The accuracy of radar measurements was restricted to $0.06^{\circ}$ in angle (azimuth, elevation) and $10 \mathrm{~m}$ in range. Minimum and maximum ranges for radar tracking of bird targets are about $1 \mathrm{~km}$ and $15-20 \mathrm{~km}$, respectively. Possible elevation angles range from a few degrees below horizontal up to about $88^{\circ}$ (almost vertical). While the radar was following a target in automatic tracking mode, readings of range, elevation, and azimuth angles were generally captured and stored on a computer every $1 \mathrm{~s}$ in PV301 and every $2 \mathrm{~s}$ in PV882. Simultaneous readings of the ship's speed and direction (heading, yaw) were obtained every second from the ship's navigation system and automatically recorded on a computer, as was information about pitch and roll that was read from a custom-designed inclinometer. This information was used to correct for speed, direction, and movements of the ship during bird tracking or wind measurement (see below).

The corrected data were used to calculate horizontal and vertical coordinates, recorded in polar co-ordinates but transformed into a Cartesian ( $\mathrm{x}, \mathrm{y}, \mathrm{z})$ coordinate system. Positions and altitudes were averaged and used to calculate track direction, ground speed, and vertical speed of the target for successive $10 \mathrm{~s}$ intervals. Each tracking was inspected, and episodes where the radar was off the target or had shifted to another target were edited. When the same flock was tracked by both radars, only one track was included in the data. Each track of more than $20 \mathrm{~s}$ duration was then entered into the data set as an independent observation. During high migration intensity, echoes were often abandoned after a maximum of $180 \mathrm{~s}$ in favor of finding and tracking a new target.

Wind direction and speed were measured by releasing and tracking helium-filled balloons with attached aluminum-foil reflectors. From these trackings, wind profiles were calculated as mean velocity for $30 \mathrm{~s}$ intervals, corresponding to altitudinal distances of approximately $75 \mathrm{~m}$. The track vector is the horizontal projection of the bird's movement in relation to the ground (which is the sum of the heading and wind vectors). We obtained airspeeds and heading directions of bird tracks by subtracting the wind vector from the track vector, using wind data from the altitude of the bird track. We calculated airspeed and heading only if wind data became available within two hours of a bird tracking. No correction was made for vertical winds. Level flight was defined as tracks with vertical speed $\left|U_{z}\right| \leq 0.4 \mathrm{~m} / \mathrm{s}$; descending flight, as $U_{z}<-0.8 \mathrm{~m} / \mathrm{s}$; diving flight, as $U_{z}<-1.6 \mathrm{~m} / \mathrm{s}$; and steep climbs, as $U_{z}>0.8 \mathrm{~m} / \mathrm{s}$. For analyses of migration flight speeds, we excluded tracks below an altitude of $250 \mathrm{~m}$ to avoid local foraging flights (see e.g., Hedenström et al., 2002).

Each tracking was reduced to an overall mean altitude, mean speeds (vertical, ground, air, and wind speeds), and directions (track, heading, and wind direction). Mean direction and scatter about the mean for sub-samples associated with the different areas (Fig. 1) were calculated as vector directions and mean vector length ( $\mathrm{r}$, where the length of the vector is inversely proportional to scatter) or mean axis direction and length $\left(\mathrm{r}_{2}\right)$ in cases of bimodal distributions (Batschelet, 1981). Time of day was registered as UTC (= GMT) and calculated into exact local times according to actual longitude at the location.

The methods used here were very similar to those used during two previous expeditions along the Northeast Passage (Alerstam and Gudmundsson, 1999a) and the Northwest Passage (Gudmundsson et al., 2002), allowing comparison of the results from the three studies.

\section{RESULTS}

\section{Characteristic Results}

A total of 203 hours of radar operation resulted in a grand total of 557 bird tracks (Table 1), and of these, 474 yielded estimates of heading direction and airspeed. Tracking time varied between 20 and $604 \mathrm{~s}$ for individual trackings, with a mean of $120 \mathrm{~s}$ and a total cumulated time of 18 hours $37 \mathrm{~min}$. The number of trackings varied between the seven areas, with $45 \%$ of the total recorded at the Koluchinskaya site (Area D, Table 1). Area-specific numbers of trackings, altitudes (mean and maximum), speeds (ground-, air- vertical-, and wind speed), directions (track, heading, and wind), and migration intensity are summarized in Table 1. For two areas (C and D), the data are also subdivided on the basis of the track direction (towards $\mathrm{W}$ or $\mathrm{E}$ ). 
TABLE 1. Summary statistics of radar tracking in the Beringia region as recorded in the summer of 2005, divided into seven different regions (see Fig. 1 for area definition). The number of observations is the total number of trackings with matching wind measurement within parentheses. Altitudes are in meters above sea level, with standard deviation (SD) in parentheses. Ground speed $\left(\mathrm{V}_{\mathrm{g}}\right)$, airspeed $\left(\mathrm{V}_{\mathrm{a}}\right)$, vertical speed $\left(\mathrm{V}_{\mathrm{z}}\right)$, and wind speed $\left(\mathrm{V}_{\mathrm{w}}\right)$ are given as area-specific mean values with SD in parentheses. Directions are given in degrees, with mean vector length (r) in parentheses. Areas C and D are divided into east (E) and west (W) groups on the basis of track directions.

\begin{tabular}{|c|c|c|c|c|c|c|c|c|c|c|c|}
\hline \multirow[b]{2}{*}{ Area } & \multirow{2}{*}{$\begin{array}{c}\text { Number of } \\
\text { Observations }\end{array}$} & \multicolumn{2}{|c|}{$\begin{array}{l}\text { Altitude } \\
\text { (m) }\end{array}$} & \multicolumn{4}{|c|}{$\begin{array}{c}\text { Speed } \\
(\mathrm{m} / \mathrm{s})\end{array}$} & \multicolumn{3}{|c|}{ Direction } & \multirow{2}{*}{$\begin{array}{c}\text { Intensity } \\
\text { (Tracks/Hr) }\end{array}$} \\
\hline & & Mean & $\operatorname{Max}$ & $\mathrm{V}_{\mathrm{g}}$ & $\mathrm{V}_{\mathrm{a}}$ & $\mathrm{V}_{\mathrm{z}}$ & $\mathrm{V}_{\mathrm{w}}$ & Track & Heading & Wind & \\
\hline A North of Wrangel Island & $49(44)$ & $1267(746)$ & 3569 & $15.9(4.5)$ & $13.5(4.2)$ & $0.10(1.46)$ & $8.1(3.5)$ & $88^{\circ}(0.84)$ & $122^{\circ}(0.81)$ & $223^{\circ}(0.93$ & 1.5 \\
\hline B South of Wrangel Island & $32(7)$ & $1468(962)$ & 3442 & $16.2(3.8)$ & $15.9(3.8)$ & $0.18(1.47)$ & $4.0(0.6)$ & $99^{\circ}(0.92)$ & $93^{\circ}(0.97)$ & $263^{\circ}(0.97$ & 2.3 \\
\hline C Chukchi Sea & $67(52)$ & $849(640)$ & 2961 & $14.1(4.9)$ & $12.3(3.3)$ & $0.06(0.79)$ & $7.0(1.5)$ & $163^{\circ}(0.27)$ & $116^{\circ}(0.15)$ & $71^{\circ}(0.89)$ & 2.4 \\
\hline C Chukchi Sea (W) & $29(27)$ & $570(177)$ & 1075 & $16.2(4.3)$ & $11.1(3.5)$ & $0.31(0.76)$ & $7.6(1.6)$ & $268^{\circ}(0.76)$ & $292^{\circ}(0.60)$ & $68^{\circ}(1.00)$ & \\
\hline C Chukchi Sea (E) & $38(25)$ & $1062(774)$ & 2961 & $12.5(4.7)$ & $13.6(2.7)$ & $-0.13(0.77)$ & $6.4(1.1)$ & $121^{\circ}(0.84)$ & $113^{\circ}(0.97)$ & $76^{\circ}(0.78)$ & \\
\hline D Koluchinskaya Bay & $252(237)$ & $850(594)$ & 3844 & $18.0(6.5)$ & $14.6(3.9)$ & $0.11(1.38)$ & $13.2(2.9)$ & $71^{\circ}(0.44)$ & $147^{\circ}(0.51)$ & $215^{\circ}(0.86$ & 4.3 \\
\hline D Koluchinskaya Bay (W) & $73(71)$ & $705(498)$ & 2245 & $12.5(5.3)$ & $15.7(3.8)$ & $-0.09(1.47)$ & $13.2(3.3)$ & $290^{\circ}(0.81)$ & $235^{\circ}(0.86)$ & $185^{\circ}(0.95$ & \\
\hline D Koluchinskaya Bay (E) & $179(166)$ & $910(621)$ & 3844 & $20.2(5.6)$ & $14.1(3.9)$ & $0.19(1.34)$ & $13.2(2.8)$ & $85^{\circ}(0.91)$ & $120^{\circ}(0.81)$ & $228^{\circ}(0.90$ & \\
\hline E Northwest of Alaska & $61(52)$ & $2029(965)$ & 4578 & $11.3(4.8)$ & $13.5(2.6)$ & $-0.19(1.21)$ & $5.8(3.1)$ & $111^{\circ}(0.62)$ & $127^{\circ}(0.88)$ & $157^{\circ}(0.95$ & 3.3 \\
\hline F West of Alaska & $19(7)$ & $1625(235)$ & 3743 & $12.3(3.0)$ & $15.0(3.7)$ & $0.66(1.97)$ & $3.9(1.8)$ & $97^{\circ}(0.69)$ & $89^{\circ}(0.58$ & $121^{\circ}(0.99)$ & 1.5 \\
\hline G Bering Strait & $77(75)$ & $1550(919)$ & 4023 & $14.5(5.5)$ & $14.9(3.6)$ & $-0.37(1.44)$ & $10.0(4.9)$ & $129^{\circ}(0.81)$ & $171^{\circ}(0.82)$ & $240^{\circ}(0.65$ & 2 \\
\hline Total & $557(474)$ & $1175(855)$ & 4578 & $15.8(6.1)$ & $14.2(3.8)$ & $0.03(1.36)$ & $10.5(4.4)$ & $98^{\circ}(0.51)$ & $143^{\circ}(0.56)$ & $206^{\circ}(0.60$ & 2.7 \\
\hline
\end{tabular}

Graphical representations of the track directions are shown in Figure 2 as circular diagrams, one for each area and one for the combined data. Only two of the echoes were positively identified to species: the first as two glaucous gulls (Larus hyperboreus) soaring and then flying towards NW, and the second as a single pomarine jaeger (Stercorarius pomarinus), likewise flying towards NW. Both were identified on 6 August at Koluchinskaya Bay.

\section{Intensity of Migration}

The overall migration intensity was 2.7 echoes/hour (Table 1). The intensity varied by a factor of 2.9 between the areas of lowest intensity (A and F, with 1.5 echoes/ hour) and that of highest intensity (D, with 4.3 echoes/hour) (Table 1). At the turning point north of Wrangel Island (Fig. 1), we had almost 14 hours of radar operation without a single bird echo. Excluding this period, the intensity for area A (2.6 echoes/hour) was more similar to that found at the offshore areas B and C (Table 1). The highest intensity was found at area D, when the ship was anchored close to the coast at Koluchinskaya Bay.

Although there was light almost throughout the day at the time of this study, there was nevertheless a clear diurnal pattern of radar echoes. Timing of our 557 echoes during different six-hour intervals was distributed as (local times): 0000-0600: 23\%; 0600-1200: 17\%; 1200-1800: 16\%; 1800-2400: 44\%.

\section{Directions of Migration}

The overall mean track direction for the combined data was $98^{\circ}$, approximately towards E (Table 1), while inspection of the circular distribution of all areas shows a bimodal distribution (Fig. 2, Table 2). Even though the axial bimodal distribution was highly significant $\left(\mathrm{r}_{2}=0.47, \mathrm{n}=557\right.$, $p<0.001$, Rayleigh test; Batschelet, 1981), the vector was shorter than the unimodal mean vector $(\mathrm{r}=0.51, \mathrm{n}=557$, Table 1). The bimodal E-W axis $\left(102-282^{\circ}\right)$ is nevertheless very close to the direction of the unimodal mean vector $\left(98^{\circ}\right)$. Migration towards the E sector dominated, with $79 \%$ of all tracks falling between $0^{\circ}$ and $180^{\circ}$. If the migration directions are classified into four $90^{\circ}$ sectors centered on the cardinal points $\left(\mathrm{N}=315-45^{\circ} ; \mathrm{E}=45-135^{\circ} ; \mathrm{S}=135-225^{\circ}\right.$; and $\left.\mathrm{W}=225-315^{\circ}\right)$, their distribution is as follows: $10 \%$ $\mathrm{N}, 63 \% \mathrm{E}, 13 \% \mathrm{~S}$, and $14 \% \mathrm{~W}$ (Table 3 ). The overall mean heading direction was $143^{\circ}$, i.e., south of the track direction, suggesting a dominance of southerly winds (Table 1).

\section{Comparison among Sites}

The proportions $(\%)$ of track directions falling in the broad N, E, S, W segments defined above are shown for areas $\mathrm{A}-\mathrm{G}$ in Table 3. Eastward migration dominates in all areas, with ca. 90\% towards $\mathrm{E}$ at the Wrangel Island sites (areas A and B; Table 3). The bimodality featured in the combined data (Fig. $2 \mathrm{~g}$ ) is mainly due to bimodal distributions in areas $\mathrm{C}$ and $\mathrm{D}$ (Fig. 2c, d; Table 3), where as many as 30\% (C) and $20 \%$ (D) of the tracks fall in the $\mathrm{W}$ segment. The mean vector lengths of the axial data (double angles; Batschelet, 1981) were larger than those of the unimodal samples (area C: $r_{2}=0.38$ vs. $r=0.27$; area $D: r_{2}=0.55$ vs. $r=0.44$ ) in areas $C$ and $D$, statistically underlining the true bimodality in these areas.

Northward migration occurred in all areas except B, and it is notable that even in area A (north of Wrangel Island), some tracks (6\%, or 3 echoes) moved northward (Fig. 2a). Southward migration of any significance occurred only in areas $\mathrm{C}$, E, and G (Table 3, Fig. 2), all of which are offshore areas. South-directed movements of Arctic terns (Sterna paradisaea), red phalaropes (Phalaropus fulicarius), and jaegers were observed especially in area G, Bering Strait (see below).

The area-specific circular distributions of track directions are displayed in Figure 2. The mean direction of $88^{\circ}$ in area 
A

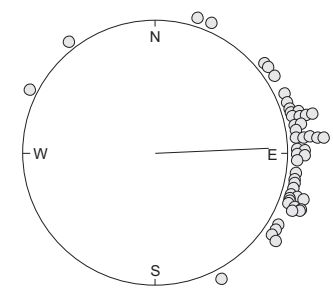

B

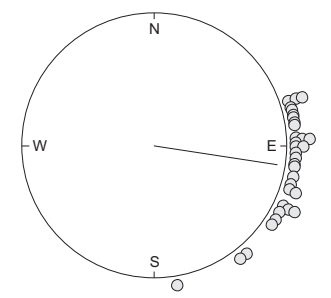

C

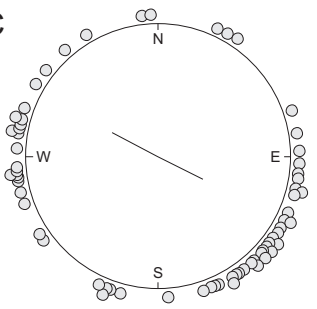

$\mathrm{D}$

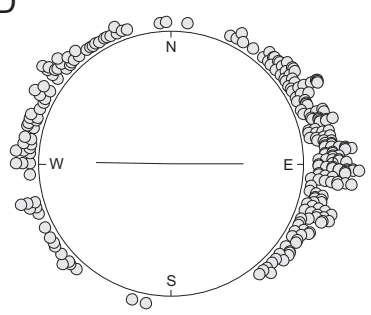

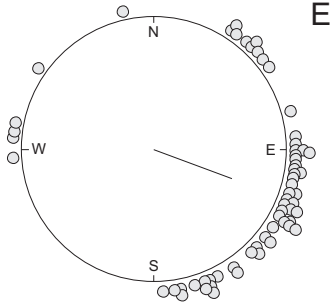
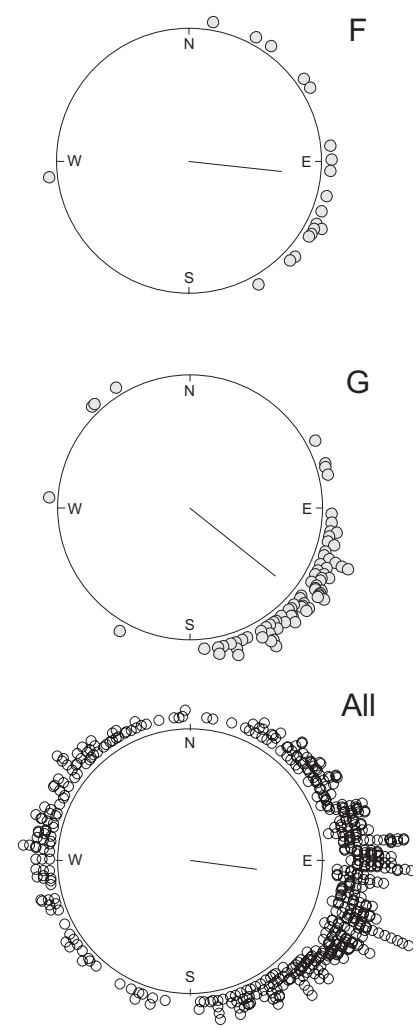

FIG. 2. Circular diagrams showing the distribution of track directions for the seven areas shown in Fig. 1 (A-G), and for the combined sample (All). Arrows show the mean direction, and the vector length $(\mathrm{r})$ is a measure of the angular spread. For areas C and D, the cases of bimodal distribution (when $r_{2}>r_{1}$; see Batschelet, 1981), the axial direction is given instead of the mean direction. Statistical significance according to the Rayleigh test (Batschelet, 1981) was $p<0.001$ in all cases. Mean or axial direction, vector length, and sample size for the different circle diagrams are given in Table 2.

A implies that these birds have to shift their course to the south in order to reach the coast of N Alaska or Canada. The mean direction of $111^{\circ}$ in area $\mathrm{E}$ (NW of Alaska) suggests that this shift does indeed occur (Fig. 2E). The mean track direction from area $\mathrm{F}$ (W of Alaska) is almost due $\mathrm{E}\left(97^{\circ}\right)$, while farther south in the Bering Strait the mean course is shifted more towards $\mathrm{S}\left(129^{\circ}\right)$.

\section{Flight Altitudes}

Overall mean and median altitudes of migrating birds were $1175 \mathrm{~m}$ and $853 \mathrm{~m}$, respectively. Altitudes above $1 \mathrm{~km}$ were noted in $42.2 \%$ of the tracks, with $25.0 \%$ in the interval $1-2 \mathrm{~km}, 12.9 \%$ at $2-3 \mathrm{~km}, 3.8 \%$ at $3-4 \mathrm{~km}$, and $0.5 \%$ above $4 \mathrm{~km}$ (Fig. 3). The maximum altitude recorded was $4578 \mathrm{~m}$ for a flock in area $\mathrm{E}$ (Table 1). The mean altitudes

TABLE 2. Mean or axial direction, vector length, and sample size for each area and for the total region (see Fig. 2).

\begin{tabular}{lccc}
\hline \hline Sector & $\begin{array}{c}\text { Mean }(\alpha) \text { or Axial }\left(\alpha_{2}\right) \\
\text { Direction }\end{array}$ & $\begin{array}{c}\text { Vector Length } \\
\left(\text { r or r }_{2}\right)\end{array}$ & Sample Size (n) \\
\hline A & $88^{\circ}$ & 0.84 & 49 \\
B & $99^{\circ}$ & 0.92 & 32 \\
C & $117-297^{\circ}$ & 0.38 & 67 \\
D & $91-271^{\circ}$ & 0.54 & 252 \\
E & $111^{\circ}$ & 0.62 & 61 \\
F & $97^{\circ}$ & 0.69 & 19 \\
G & $129^{\circ}$ & 0.81 & 77 \\
All & $98^{\circ}$ & 0.51 & 557 \\
\hline \hline
\end{tabular}

at the different areas of the Chukchi Sea and Koluchinskaya Bay were below $1000 \mathrm{~m}$, while at the NW Alaska area the mean altitude was $2029 \mathrm{~m}$ (Table 1).

In Figure 4, flight altitudes are plotted in relation to track direction for all data combined. High altitudes $(>1.5 \mathrm{~km})$ were associated mainly with eastbound migration between $50^{\circ}$ and $170^{\circ}$; only a few westbound tracks reached this altitude in the $250-340^{\circ}$ sector. Flight altitude also showed an increasing trend with increasing latitude (Fig. 5a), a relationship that was particularly clear north of Wrangel Island (Fig. 5b).

\section{Flight Speeds}

Level flight $\left(\left|U_{z}\right| \leq 0.4 \mathrm{~m} / \mathrm{s}\right)$ was recorded for $31.6 \%$ of the total sample (total $\mathrm{n}=453$ ), while descending flights comprised $35.5 \%$ and ascending flights $32.9 \%$. Vertical speeds ranged from $-5.52 \mathrm{~m} / \mathrm{s}$ (descent) to $4.5 \mathrm{~m} / \mathrm{s}$ (climb), with an overall mean of $-0.035 \mathrm{~m} / \mathrm{s}$ that was not significantly different from zero $(p>0.05)$. Among the descents, $22.3 \%$ were steep and $9.7 \%$ were very steep or dives. The proportion of steep climbs was $20.5 \%$, and climbs faster than $1.6 \mathrm{~m} / \mathrm{s}$ were found in $8.6 \%$ of the tracks.

The overall distributions of ground speeds, airspeeds, and wind speeds are shown in Figure 6. Ground speed showed a mean of $15.9 \mathrm{~m} / \mathrm{s}(\mathrm{SD}=0.29, \mathrm{n}=453)$, which was somewhat larger than the mean airspeed of $14.1 \mathrm{~m} / \mathrm{s}(\mathrm{SD}=$ $0.18)$. Hence, on average, birds migrated with a small tailwind component that was significantly larger than zero $(\mathrm{t}=$ $5.78, \mathrm{df}=452, p<0.001)$. Analyzing only tracks classified as level flight resulted in a mean airspeed of $13.4 \mathrm{~m} / \mathrm{s}(\mathrm{n}=$ 143), which was slightly less than that of the total sample. The varying wind conditions characteristically increase the variance of ground speeds in relation to airspeeds (Fig. 6). On average, birds migrating eastward enjoyed tail winds to a larger extent than those migrating westward (Fig. 7).

To test which of the potential variables contributed to the observed variation in airspeed, we performed a multiple regression analysis with tail wind and side wind components, vertical speed, and altitude as independent variables. This analysis showed that only the tail wind component (Fig. 8a; $\mathrm{t}=-6.1$, $\mathrm{df}=4,469, p<0.001$ ) and vertical speed (Fig. $8 \mathrm{~b} ; \mathrm{t}=-3.5, \mathrm{df}=4,469, p<0.001$ ) independently contributed to the variation in airspeed. 
TABLE 3. Relative distribution of radar track directions $(\alpha)$ within different sectors defined as $\mathrm{N}(315<\alpha<45)$, E $(45<\alpha<135)$, $\mathrm{S}$ $(135<\alpha<225)$, and $\mathrm{W}(225<\alpha<315)$, for each of seven different areas of the Beringia region shown in Figure 1.

\begin{tabular}{lccccc}
\hline \hline Area & $\mathrm{N}(\%)$ & $\mathrm{E}(\%)$ & $\mathrm{S}(\%)$ & $\mathrm{W}(\%)$ & Number \\
\hline A & 6 & 90 & 2 & 2 & 49 \\
B & 0 & 91 & 9 & 0 & 32 \\
C & 10 & 33 & 27 & 30 & 67 \\
D & 12 & 65 & 3 & 20 & 252 \\
E & 11 & 56 & 25 & 8 & 61 \\
F & 16 & 74 & 5 & 5 & 19 \\
G & 4 & 58 & 37 & 1 & 77 \\
Total & 10 & 63 & 13 & 14 & 557 \\
\hline \hline
\end{tabular}

Overall the mean airspeeds varied from $11.1 \mathrm{~m} / \mathrm{s}$ (tracks between $180^{\circ}$ and $360^{\circ}$ ) in area $\mathrm{C}$ to $15.9 \mathrm{~m} / \mathrm{s}$ in area $\mathrm{B}$, and there were significant differences in airspeeds among the areas (ANOVA, $\mathrm{F}_{4,467}=3.99, p<0.001$ ). In area $\mathrm{C}$, eastbound tracks had a mean airspeed of $\bar{U}_{a}=12.9 \mathrm{~m} / \mathrm{s}(\mathrm{SD}=$ $2.8, \mathrm{n}=13)$ and westbound tracks had $\bar{U}_{a}=9.8 \mathrm{~m} / \mathrm{s}(\mathrm{SD}$ $=1.8, \mathrm{n}=19)$, which are significantly different from each other $(\mathrm{t}=3.84, p<0.001)$. Hence, birds flying towards $\mathrm{W}$ do so approximately $3 \mathrm{~m} / \mathrm{s}$ slower than those flying towards E. In area $\mathrm{D}$, westbound tracks had a higher mean airspeed at $\bar{U}_{a}=16.5 \mathrm{~m} / \mathrm{s}(\mathrm{SD}=3.3, \mathrm{n}=50)$ than the eastbound tracks at $\bar{U}_{a}=14.0 \mathrm{~m} / \mathrm{s}(\mathrm{SD}=3.6, \mathrm{n}=152)(\mathrm{t}=4.39, \mathrm{df}=200$, $p<0.001)$.

The echoes identified as two glaucous gulls and a pomarine jaeger had airspeeds of 18.0 and $18.4 \mathrm{~m} / \mathrm{s}$, respectively.

\section{Migrating Birds Observed in the Beringia Region during the 2005 Expedition}

Observations of birds at five land sites are summarized in Appendix 1. Shorebirds constitute the largest group, both in diversity and numbers, but migrating ducks, geese, jaegers, gulls, terns, and passerines were also observed.

The most numerous migrants both on land sites and at sea were shorebirds, particularly red phalaropes and red-necked phalaropes (P. lobatus), dunlins (Calidris alpina), western sandpipers, and red-necked stints ( $C$. ruficollis). The majority of shorebird observations referred to foraging flocks at land sites. Large mixed-species flocks of red and red-necked phalaropes were feeding at sites 2, 3, and 5, that is, on both sides of the Chukchi Sea. At Barrow, the numbers of staging phalaropes increased between the first visit on 20 July and the second on 20 August. Movements of red phalaropes, sometimes of great intensity, were also seen from the ship almost daily throughout the passage of the Bering Strait and the Chukchi Sea, with most flocks flying towards E/SE. In one particular area north of the Bering Strait, intensive and directed movements of red phalaropes were observed flying towards SE. Single red phalaropes flying eastward were also observed at quite high latitudes, both north of Wrangel Island and in the Beaufort Sea.

Flocks of dunlins were observed in greatest numbers at Koluchinskaya Bay and on Wrangel Island, and in moderate

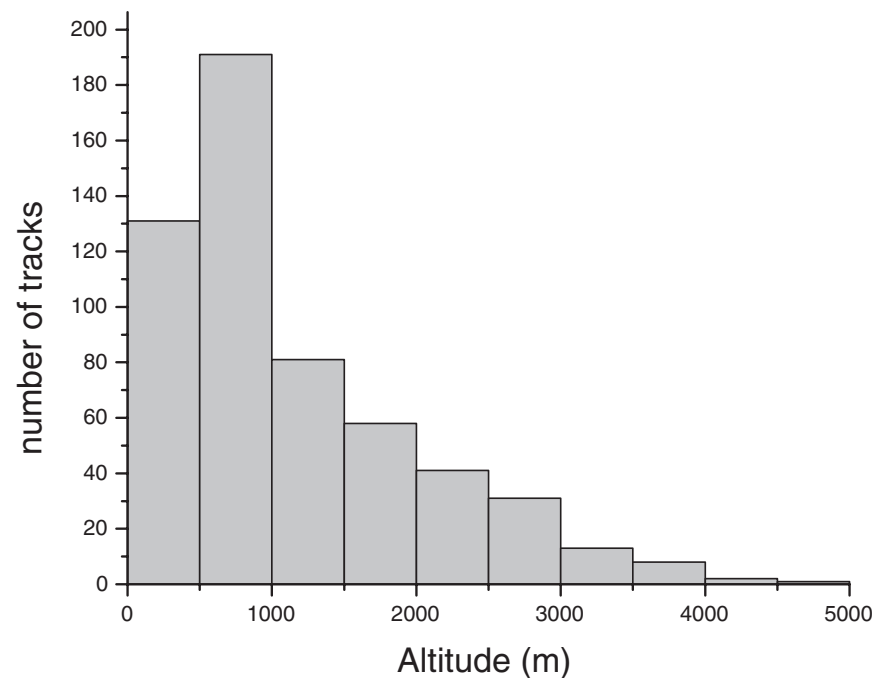

FIG. 3. Altitude of bird echoes recorded by tracking radar. Histogram bars represent $500 \mathrm{~m}$ intervals. Mean altitude is $1157 \mathrm{~m}$.

numbers at Mekigney Bay and Barrow. Occasionally, small numbers of migrating dunlins were observed from the ship in the Chukchi Sea.

Western sandpipers were represented in fair numbers, particularly at the Chukotka land sites. Flocks of juveniles were observed feeding in these wetlands. It was notable that western sandpipers often occurred in flocks together with juvenile red-necked stints considering that these species winter separately, the first in the Americas and the second in SE Asia and Australia.

Red knots (Calidris canutus) and ruddy turnstones (Arenaria interpres) were quite common on Wrangel Island and at Koluchinskaya Bay. The red knots breeding on the Chukotka peninsula and Wrangel Island are considered to be members of the subspecies rogersi, with wintering grounds primarily in N Australia and New Zealand, while red knots breeding in Alaska belong to the subspecies roselaari, with wintering grounds in the Americas. Only occasional observations of migrating red knots were made from the ship.

Long-billed dowitchers (Limnodromus scolopaceus) were occasionally seen at Mekigney Bay, while substantial flocks were observed at Barrow. Long-billed dowitchers overwinter in North America, and so birds of Siberian origin do migrate eastward across the Bering Strait or the Chukchi Sea.

Pectoral sandpipers were commonly observed throughout the region, but only in small flocks of 1-5 individuals. Observations were made of pectoral sandpipers migrating eastward at quite northerly latitudes (about $72^{\circ} \mathrm{N}$ ), such as in the northern Chukchi Sea NE of Herald Island and in the Beaufort Sea north of Point Barrow near the pack-ice edge (about $73^{\circ} \mathrm{N}$ ).

Other shorebirds observed in small numbers on the land sites are listed in Appendix 1. These include sanderling (Calidris alba), sharp-tailed sandpiper (C. acuminata), semi-palmated sandpiper $(C$. pusilla), rock sandpiper $(C$. ptilocnemis), spoon-billed sandpiper (Eurynorhynchus 


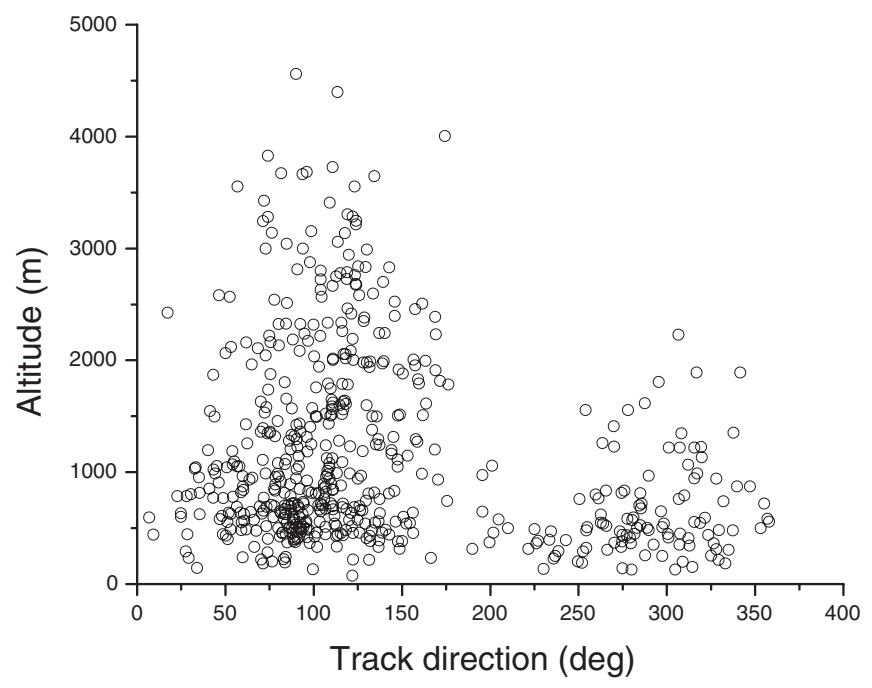

FIG. 4. Altitude of bird echoes recorded by tracking radar in relation to track direction, where $0^{\circ}$ is north, $90^{\circ}$ is east, $180^{\circ}$ is south, and $270^{\circ}$ is west.

pygmaeus) and ruff (Philomachus pugnax) at Koluchinskaya Bay, and semipalmated plover (Charadrius semipalmatus), Baird's sandpiper (Calidris bairdii) and semipalmated sandpiper at Barrow. At Koluchinskaya Bay and Wrangel Island some species were still on breeding territories or were brooding young, including Temminck's stint (Calidris temminckii), ringed plover (Charadrius hiaticula), Pacific golden plover (Pluvialis fulva) and black-bellied plover (P. squatarola).

Among the Anseridae, flocks of king eiders (Somateria spectabilis) and especially common eiders (S. mollissima) were frequently observed flying in fairly large numbers along the coasts of almost all sites, as well as farther out to sea. The directions of these flocks were quite variable and may often have represented local movements between foraging sites rather than migration. However, at Barrow (Fig. 1), flocks consistently kept a westerly direction. Although the movements of eiders throughout the region were quite substantial, eiders are unlikely to represent a significant fraction of radar tracks except at area D (see below). Generally eiders fly at quite low elevations when migrating over sea (Alerstam et al., 1974; Karlsson, 1976), often below the minimum elevation recorded by the radar.

Other ducks, such as northern pintails (Anas acuta) and oldsquaws or long-tailed ducks (Clangula hyemalis), were seen in migratory (and molting) flocks in ponds and along the shoreline, especially at Wrangel Island and at Barrow.

Flocks of emperor geese (Chen canagica) were observed foraging and resting along the shores of the Mekigney Bay site, as well as foraging in flocks together with brant geese (Branta bernicla) at Koluchinskaya Bay. Substantial flocks of brant geese were observed at both Koluchinskaya Bay and Wrangel Island. Furthermore, flocks of brant geese and white-fronted geese (Anser albifrons) were observed flying westward and northward in the Barrow area.

Extensive westward movements of snow geese (Chen caerulescens) were observed on Wrangel Island. These birds
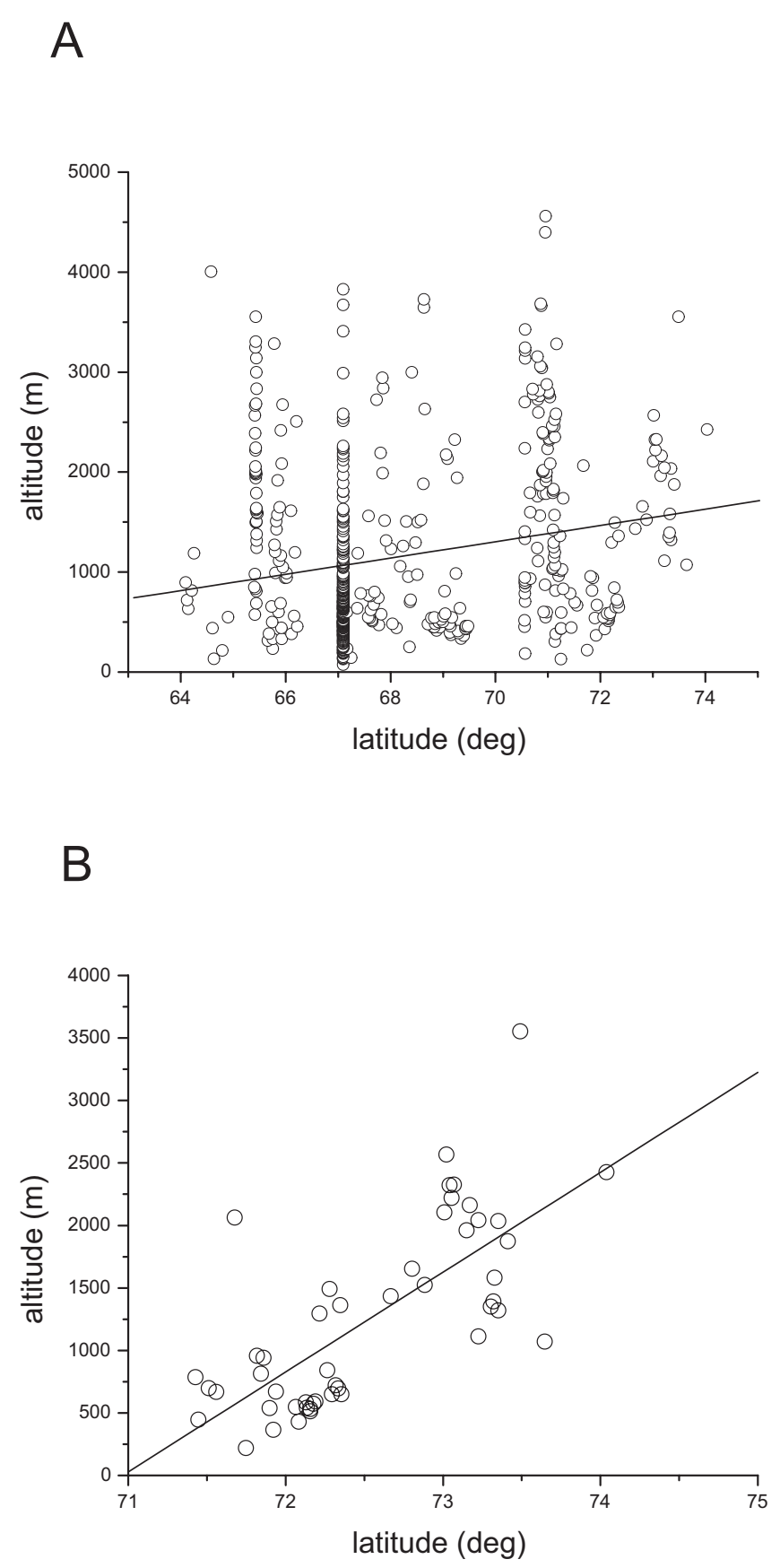

FIG. 5. Altitude of bird echoes recorded by tracking radar in relation to latitude (A) for the total sample (regression: Altitude $=-4400+81.5$ Latitude; statistics for slope: $\left.\mathrm{t}=4.96, r^{2}=0.042, p<0.0001, \mathrm{n}=557\right)$ and (B) for area A, $\mathrm{N}$ of Wrangel Island (regression: Altitude $=-56709+799$ Latitude; statistics for slope: $\mathrm{t}=7.11, r^{2}=0.52, p<0.0001, \mathrm{n}=49$ ).

were presumably en route to staging sites somewhere to the west on the coastal Siberian tundra before commencing the easterly migration to wintering grounds in North America.

Long-tailed jaegers (Stercorarius longicaudus) and pomarine jaegers, and to a lesser extent, parasitic jaegers $(S$. parasiticus), were frequently observed hunting across the tundra near wetlands at the different land sites. Observations of migrating jaegers, mainly pomarine and long-tailed, were made from the ship in the Chukchi Sea and north of 

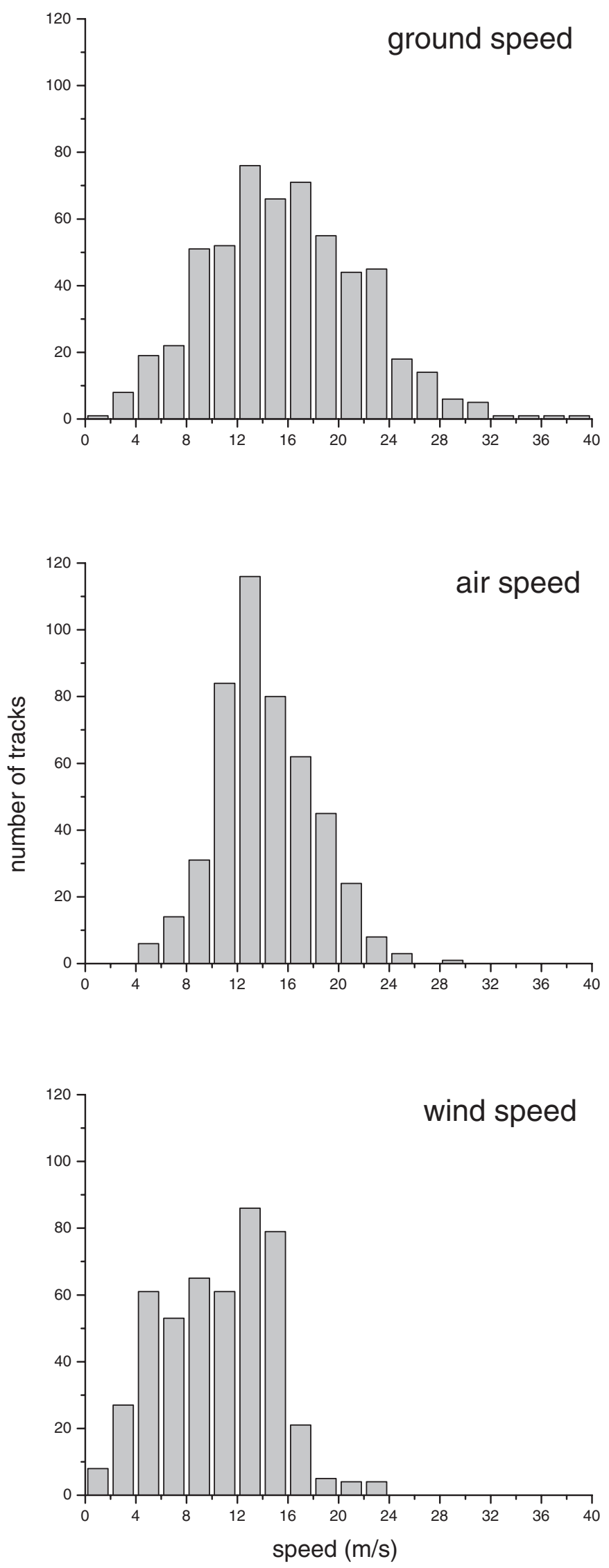

FIG. 6. Distributions of ground speeds, airspeeds, and wind speeds as recorded by tracking radar in Beringia in 2005. Bars represent $2 \mathrm{~m} / \mathrm{s}$ intervals. The graphs show the total data set.

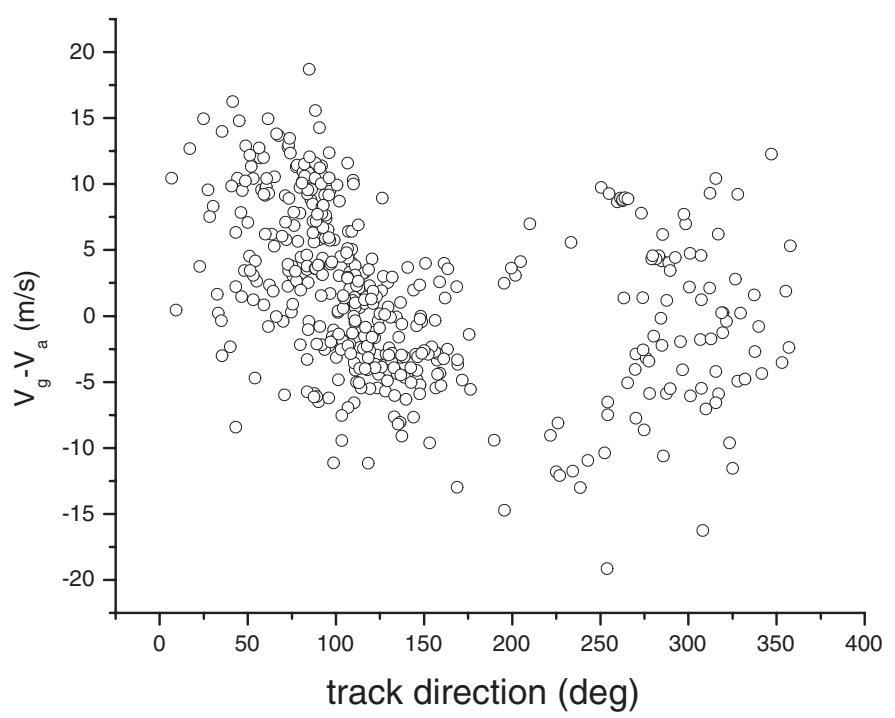

FIG. 7. Wind effect $\left(V_{g}-V_{a}\right)$ in relation to track direction $(n=474)$, where $0^{\circ}$ is north.

the Bering Strait. Also seen well north of the pack-ice limit at about $77^{\circ} \mathrm{N}$ were a few pomarine jaegers heading $\mathrm{E}$ and long-tailed jaegers heading between $\mathrm{E}$ and S. One visually identified radar echo was of a pomarine jaeger off the coast at Koluchinskaya Bay heading NW.

In the northern Chukchi Sea, north of Wrangel Island, a few migrating arctic terns were observed (e.g., a flock of about 11 individuals at about $72^{\circ} \mathrm{N}$ migrating towards east). At the land sites at Koluchinskaya Bay and Wrangel Island, arctic terns were seen still in breeding colonies with chicks on 15 August.

The most commonly observed passerine species appearing at the Chukotka land sites in significant numbers that indicated migratory behaviour were eastern yellow wagtail (Motacilla tschutschensis), American pipit (Anthus rubescens), lapland longspur (Calcarius lapponicus), snow bunting (Plectrophenax nivalis), common redpoll (Carduelis flammea) and hoary redpoll (C. hornemanni). Single individuals of savannah sparrow (Passerculus sandwichensis), northern wheatear, arctic warbler, and yellow wagtail were also observed landing on the ship far off the coasts of Siberia and Alaska.

\section{DISCUSSION}

\section{Beringia as a Hot Spot for Bird Migration between Asia and America}

Our radar observations of migrating birds in Beringia revealed a rather complicated picture composed of migration in many directions. The main finding is the existence of significant exchanges between Asia and North America. The dominating migration flow was directed eastward, but migration occurred in all quadrants centered on the four main geographic directions. In areas $\mathrm{C}$ and $\mathrm{D}$, 
A
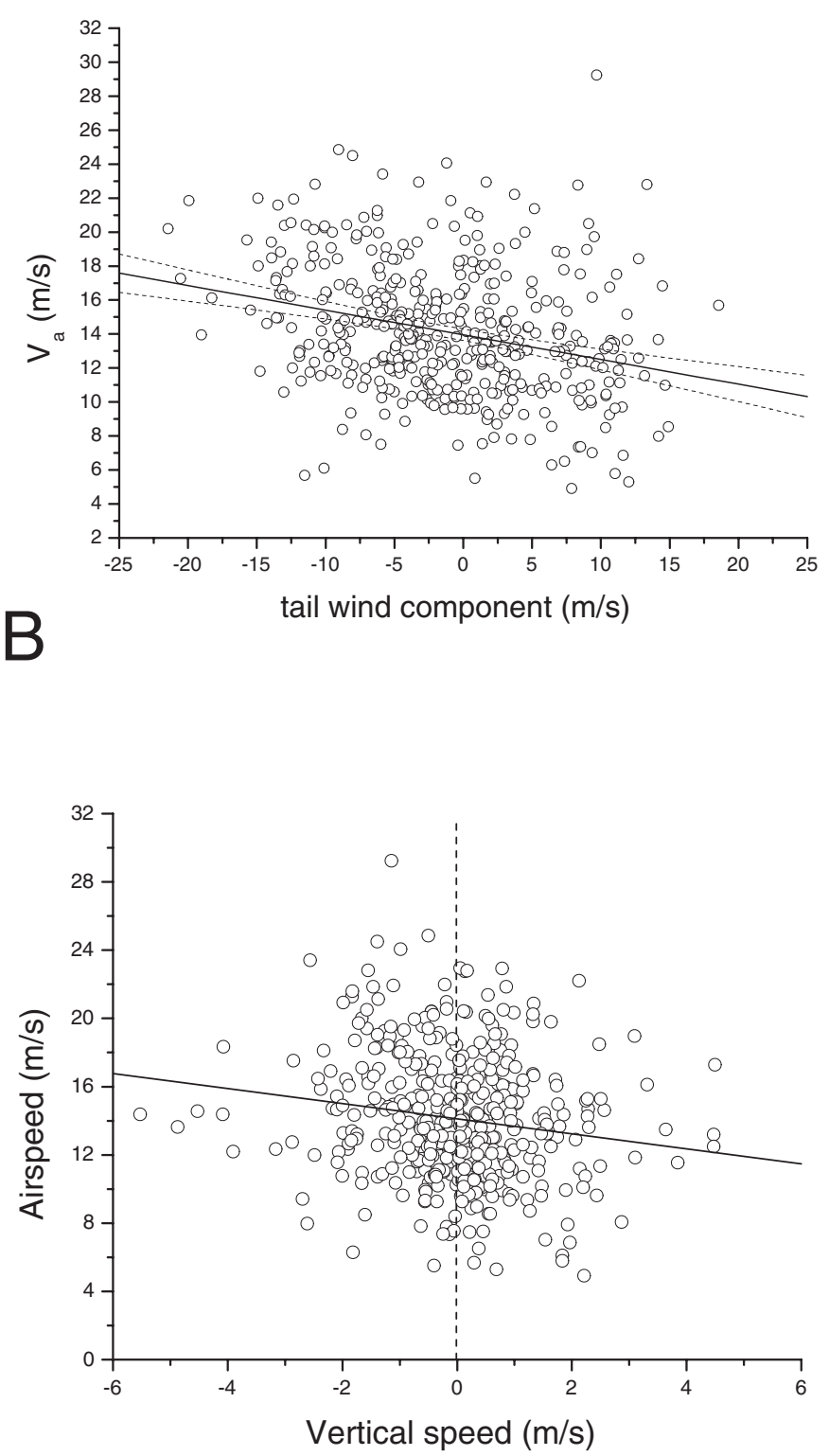

FIG. 8. (A) Airspeed $\left(\mathrm{V}_{\mathrm{a}}\right)$ in relation to tail wind component (TWcomp) for the total sample with altitudes exceeding $250 \mathrm{~m}$. The linear regression is $\mathrm{V}_{\mathrm{a}}=$ 13.9 - 0.15 TWcomp, $\mathrm{t}=6.24, p<0.0001, \mathrm{n}=453$. $(\mathrm{B})$ Airspeed $\left(\mathrm{V}_{\mathrm{a}}\right)$ in relation to vertical speed $\left(\mathrm{V}_{\mathrm{z}}\right)$ for the total sample with altitudes exceeding $250 \mathrm{~m}$. The linear regression is $\mathrm{V}_{\mathrm{a}}=14.1-0.44 \mathrm{~V}_{\mathrm{z}}, \mathrm{t}=3.28, p=0.0011, \mathrm{n}=453$.

the distributions of directions were bimodal, demonstrating simultaneous migration towards $\mathrm{E}$ and $\mathrm{W}$. The pattern that emerges suggests that Beringia is a migration hot spot with intense bird traffic between the Old and New Worlds. Which species are involved, where do they originate, and where are their destination areas? Since only two echoes were positively identified as pomarine jaeger and glaucous gull, we have to infer what species are represented among the radar echoes from other observations of migrating birds. We conclude that in addition to three species of jaeger and the arctic tern, which were all observed migrating from the ship, the majority of radar echoes were likely produced by shorebirds. Further support for this conclusion comes from the high flight altitudes, up to $4 \mathrm{~km}$, which are typical of migrating shorebirds (Flock, 1972, 1973; Richardson, 1979; Alerstam and Gudmundsson, 1999a). The migration towards $\mathrm{E}$ at significant altitudes well north of Wrangel Island very likely represents shorebirds migrating from areas farther west along the Siberian tundra coast on their way to intermediate stopover sites in North America (Alerstam et al., 2007). Some species, such as the pectoral sandpiper, breed as far west as the Yamal Peninsula and yet migrate eastward over the Arctic Ocean, passing southward across the North American continent and farther on to destinations in southern South America (Holmes and Pitelka, 1998). Other shorebird species that breed in Siberia and migrate to wintering areas in South America via the interior North American flyways include Baird's sandpiper, while species following the eastern route of the Pacific Flyway include red phalarope, western sandpiper, dunlin, and black-bellied plover. Arctic terns are also likely to show eastward migration from east Siberian breeding populations, but they probably veer southward through the Bering Strait. Yet other species, notably juvenile sharp-tailed sandpipers and turnstones, first migrate eastward from Siberia to stopover areas in Alaska, and then depart on long trans-Pacific flights to winter quarters in the Pacific, Australia, or New Zealand (Thompson, 1973; Gill and Handel, 1990; Gill et al., 2005).

Migratory directions farther south in the Bering Strait (area G) were shifted more to the southeast, which probably shows that birds are influenced by the topography and are funneled through the Bering Strait. This is likely the situation for the pelagic species such as jaegers, arctic terns, and red phalaropes, and for species entering the flyway along the North American west coast, such as western sandpiper, dunlin, and long-billed dowitcher.

The westward component may have a more diverse species composition than the eastward migration. We observed clear indications of passerine involvement from the radar echo signatures of varying echo-strength typical of intermittent flight, a conclusion also supported by the low airspeeds measured in area C (cf. Alerstam et al., 2008). Direct evidence of passerine presence was also found, as individuals of species such as wheatear, arctic warbler, and yellow wagtail were observed from the ship. A few species with a main breeding distribution in Eurasia also have breeding populations in Alaska but maintain fall migration across the Bering Strait to their species-specific wintering areas in Africa or southern Asia (Parkes and Amadon, 1948; Moreau, 1972). These species include the arctic warbler, yellow wagtail, white wagtail, red-throated pipit, northern wheatear, and bluethroat (Luscinia svecica). These trans-Beringia passerine migrants are regularly observed on St. Lawrence Island (Lehman, 2005), and to a lesser extent, on St. Matthew Island (Winker et al., 2002). Some of the westward echoes 
could also refer to the ruff, which is the only shorebird species of which the Alaskan population migrates to wintering areas in Africa (Gibson, 1977). At site D, we encountered some fast migrating echoes of birds flying towards the west, which may have been king eiders on molt migration (Flock, 1973; Johnson and Richardson, 1982), a possibility suggested also by field observations of west-directed movements. There is also a documented molt migration of emperor geese from Alaska to coastal areas around and to the west of Koluchinskaya Bay, with westward movements occurring mainly in June and the return migration in late August and September (Hupp et al., 2007). The timing of this molt migration makes it unlikely that emperor geese were involved in our tracking data.

The few echoes moving northward are unlikely to represent long-distance migration across the geographic North Pole, since bird migration appears non-existent at or near the North Pole (Gudmundsson and Alerstam, 1998). These echoes may instead refer to shorter movements by jaegers or arctic gulls to temporary feeding areas in the pack ice (Gudmundsson et al., 2002). At the northernmost turning point of the expedition at $77^{\circ} 13^{\prime} \mathrm{N}$ (Fig. 1), three juvenile Ross's gulls (Rhodostethia rosea) were observed, demonstrating the presence of these birds at such high latitudes.

The intensities of migration observed in this study were comparable to those found along the Northwest Passage in 1999 (Gudmundsson et al., 2002), but generally lower than those noted at sites along the North Siberian coast in 1994 (Alerstam and Gudmundsson, 1999a). Comparing the migration intensities of the sites showed that the highest traffic rate was at the coastal site $\mathrm{D}$, which is consistent with previous findings in the Arctic (Gudmundsson et al., 2002). Concentrations of bird migration near coasts acting as leading lines are a well-known phenomenon. It should be noted that these intensities are relative measures only, and that during periods of peak migration the intensity is underestimated because new echoes are quickly found and most time is devoted to actual tracking. The operation time also includes the tracking of weather balloons for measuring the wind, which also reduces the estimated migration intensity.

\section{Flight Routes and Orientation}

On first reflection, it may seem counter-intuitive that migration directions are mainly along an E-W axis at these very high latitudes. However, the predominant direction may be due in part to the fact that the birds' intermediate or final destinations are situated either SW or SE of the study area. But how can this explanation be reconciled with flight directions even north of the E-W axis, as found in some areas? The conclusion from previous studies in Siberia and Canada was that Arctic shorebirds (and perhaps also terns and jaegers) fly along great circle routes (orthodromes), rather than along constant geographic compass courses (loxodromes or rhumb lines) (Alerstam and Gudmundsson, 1999b; Alerstam et al., 2001). The migration along great circle routes is associated with changing orientation, but has the advantage of representing the shortest distance between two locations. For possible destinations of birds passing through the Beringia region, such as shorebirds migrating to South America and the wheatear migrating to southern Africa, migration along great circles instead of rhumb lines can reduce flying distance by $10 \%$ to $15 \%$. Departure directions observed in Beringia and other parts of the Arctic are generally consistent with great circle migration in shorebirds (Alerstam et al., 2001, 2007) and in passerines (Alerstam et al., 2008). A relatively simple mechanism that uses the sun's position and an internal clock running at the local time of flight departure allows birds to fly very close to true greatcircle routes (Alerstam and Pettersson, 1991). However, it is evident from Figure 2 and Table 3 that the migration patterns in the Beringia region form a very complex picture. Even though migration towards E dominates, there is significant migration also towards $\mathrm{W}$ and $\mathrm{S}$ in several areas. There is also migration directed towards $\mathrm{N}$ at a time of the year (August) when the expected migratory directions should be southward, but these movements may represent temporary migrations towards areas for feeding or molting.

\section{Flight Altitudes and Speeds}

The flight altitude distribution recorded in Beringia was intermediate between those of the Siberian and the Canadian Arctic. The mean (median) altitude in this study was 1175 (853) m, compared to 790 (580) m at the Northwest Passage (Gudmundsson et al., 2002), 1330 (980) $\mathrm{m}$ at the Northeast Passage (Alerstam and Gudmundsson, 1999a), and 2000 (1700) $m$ in Nova Scotia (Richardson, 1979). The maximum altitudes recorded followed the same pattern: $4.6 \mathrm{~km}$ for this study, compared to $3.95 \mathrm{~km}$ (Northwest Passage), $4.8 \mathrm{~km}$ (Northeast Passage), and $6.65 \mathrm{~km}$ (Nova Scotia). The proportion of migrants flying above $1000 \mathrm{~m}$ also followed this pattern, with $42.2 \%$ for this study, compared to 27\% (Northwest Passage), 50\% (Northeast Passage), and $75 \%$ (Nova Scotia). Two explanations were offered for the relatively low altitudes at the Northwest Passage: shorter flight steps in Canada compared to Siberia, or less favorable winds in Canada compared to Siberia, a factor that could discourage high-altitude flights (Gudmundsson et al., 2002). The winds were only marginally more favorable in the Beringia region than in the Canadian Arctic, which indicates that the flight distance explanation is the more likely one.

The positive relationship between latitude and flight altitude suggests that the number of long-distance flyers increases with latitude. This relationship was particularly clear in Area A, north of Wrangel Island, supporting the notion that echoes far out over the Arctic Ocean refer to birds flying nonstop for a long distance, such as between the Taymyr Peninsula or the New Siberian Islands and intermediate staging areas in North America (see Alerstam et al., 2007). The latitude-altitude correlation could also mean that the proportion of descending and ascending birds is higher farther south into the Bering Strait area compared with the more northern latitudes. In area A, the latitude- 
altitude correlation could mean that the southernmost echoes are birds that intend to land on Wrangel Island. Overall, the proportion of birds involved in climbing or descending flights (defined as $\left|U_{z}\right|>0.4 \mathrm{~m} / \mathrm{s}$ ) in this study (68.4\%) was larger than in the Northeast Passage (25\%; Alerstam and Gudmundsson, 1999a) and the Northwest Passage (43\%; Gudmundsson et al., 2002). Taken together, these observations suggest that Beringia is an area where migration is initiated, as well as an intermediate staging area for birds whose original starting sites are farther to the west along the Siberian coast.

Airspeed is known to be potentially affected by a number of factors, such as altitude, wind, and vertical speed (e.g., Hedenström et al., 2002 for an overview). Because of scaling effects and other factors, flight speed varies among different types and sizes of birds (Alerstam et al., 2007), and hence flight speed may be used as an indication of species identity. In the Beringia region, the overall mean airspeed was $14.1 \pm 3.7 \mathrm{~m} / \mathrm{s}$, which is very close to the means recorded at the Northeast Passage $(13.8 \pm 3.0 \mathrm{~m} / \mathrm{s}$; Alerstam and Gudmundsson, 1999a) and the Northwest Passage (13.8 $\pm 3.4 \mathrm{~m} / \mathrm{s}$; Gudmundsson et al., 2002). These comparable airspeeds suggest that similar compositions of species are involved in all three regions: mainly shorebirds, but also jaegers and terns to some extent. In this study, we observed a bimodal distribution of track directions in two areas (C and D), but the airspeeds differed. In area C, the W-directed echoes had an airspeed of $9.8 \mathrm{~m} / \mathrm{s}$, compared to $12.9 \mathrm{~m} / \mathrm{s}$ in the E-directed migrants, suggesting the presence of smaller birds (passerines) in the westbound contingent. This conclusion is consistent with the echo signatures, which showed the typical pattern of intermittent passerine flight to a significant extent in area $\mathrm{C}$ (own observation). At site $\mathrm{D}$, in contrast, the westbound migrants had higher mean airspeed $(16.5 \mathrm{~m} / \mathrm{s})$ than the eastbound migrants $(14.0 \mathrm{~m} / \mathrm{s})$, suggesting that the westward migration included larger birds than the eastbound group. However, there were also some echoes showing a typical passerine signature among those birds flying towards E (Alerstam et al., 2008). At this site, flocks of king eiders were observed flying westward, suggesting that ducks may have contributed to the relatively high mean airspeed recorded.

The selection of airspeed by birds may depend on multiple factors, not only ecological context and associated optimization criteria, but also external factors like winds, altitude (air density), and vertical speed (e.g., Pennycuick, 1978; Hedenström and Alerstam, 1995). In order to minimize energy cost per unit ground distance covered, a bird should adjust its airspeed so as to increase it when flying into a head wind and reduce it when flying with a tail wind (Pennycuick, 1978). A bird can compensate for the effect of crosswinds and maintain a constant track direction by simply changing its heading; however, to minimize energy cost per unit of distance covered over the ground, it must simultaneously adjust its airspeed with respect to the angle between track and heading (Liechti et al., 1994). Airspeed is often analyzed in relation to the wind effect
$\left(U_{g}-U_{a}\right)$, which is positive in tail winds and negative in head winds, and therefore a negative correlation is taken as evidence of an adaptive speed adjustment. However, ShamounBaranes et al. (2007) recently pointed out that in samples that included birds with various intrinsic airspeeds, such as samples derived from radar tracking of unidentified birds of mixed species, a spurious negative correlation may arise when regressing $U_{a}$ in relation to $\left(U_{g}-U_{a}\right)$. Therefore, in this study we used the tail wind component instead, defined as the wind vector projected on the heading direction, which is immune to the problems pointed out by Shamoun-Baranes et al. (2007). We found a negative correlation between airspeed and the tail wind component, which supports the prediction about energy minimization (Pennycuick, 1978).

There was also a significant effect of vertical speed on airspeed, while the multiple regression failed to show significant effects of side wind component and altitude. In the data from the Northwest Passage in 1999, there was a significant effect from the side wind component, $U_{z}$, and altitude, but not from the tail wind component (data reanalyzed using tail wind component). However, the effect of side winds was opposite from that predicted, which was interpreted as a spurious result due to a composition of flocks of mixed body size (Hedenström et al., 2002). The data set from Siberia showed significant effects on airspeed of the tail wind component, $U_{z}$, and altitude, but not of the side wind component (reanalysis of data in Alerstam and Gudmundsson, 1999a), and this pattern also holds if analyzing the combined data from all three expeditions ( $n=1771$ echoes). Hence, we may conclude that airspeed in Arctic migratory birds is generally affected by the tail wind component, vertical speed, and altitude.

\section{Arctic Bird Migration Systems}

The combined data from three ship expeditions to the Arctic show that migration occurs at high intensities and high altitudes, circumstances associated with long-distance migration of Arctic breeding birds over the Arctic Ocean. The migration pattern found in the Beringia region showed links between that found during the previous two expeditions to Siberia and Canada. The eastward-directed migration at high altitudes found over the Arctic Ocean north of Wrangel Island most likely represents a trans-continental migration from source areas in central and eastern Siberia (Alerstam and Gudmundsson, 1999a, b) to northern Alaska and the Beaufort Sea (Gudmundsson et al., 2002). The high altitude migration off the coast of NW Alaska observed in this study is likely to also represent this migration. Beringia is a major cross-road of bird migration systems involving populations breeding in Siberia and wintering in the New World, and also species breeding in Alaska and wintering in Southeast Asia or Africa. 
APPENDIX 1:

OBSERVATIONS ${ }^{1}$ OF BIRDS AT FIVE SITES² DURING THE SUMMER OF 2005 IN THE BERINGIA REGION

\begin{tabular}{|c|c|c|c|c|c|c|c|c|c|c|c|c|c|}
\hline \multirow[b]{2}{*}{ Family } & \multirow[b]{2}{*}{ Species } & \multicolumn{5}{|c|}{ Sites } & \multirow[b]{2}{*}{ Family } & \multirow[b]{2}{*}{ Species } & \multicolumn{5}{|c|}{ Sites } \\
\hline & & 1 & 2 & 3 & 4 & 5 & & & 1 & 2 & 3 & 4 & 5 \\
\hline \multirow[t]{16}{*}{ Anseridae } & Cygnus bewickii & & $\mathrm{E}$ & & & & Scolopacidae & Eurynorhynchus pygmaeus & & & $\mathrm{E}$ & & \\
\hline & Cygnus columbianus & & & & & $\mathrm{E}$ & cont: & Calidris melanotos & & $\mathrm{F}$ & $\mathrm{C}$ & $\mathrm{E}$ & $\mathrm{F}$ \\
\hline & Branta bernicla & & & A & $\mathrm{C}$ & A & & Calidris acuminata & & & $\mathrm{E}$ & $\mathrm{C}$ & \\
\hline & Branta canadensis & & & & & $\mathrm{E}$ & & Philomachus pugnax & & & E & & \\
\hline & Anser albifrons & & & & & A & & Limnodromus scolopaceus & & $\mathrm{E}$ & $\mathrm{E}$ & & A \\
\hline & Chen canagica & & $\mathrm{C}$ & A & & & & Phalaropus lobatus & & A & $\mathrm{C}$ & & A \\
\hline & Chen caerulescens & & $\mathrm{C}$ & & A & & & Phalaropus fulicaria & & $\mathrm{E}$ & A & E & A \\
\hline & Somateria mollissima & A & $\mathrm{E}$ & A & $\mathrm{C}$ & A & & & & & & & \\
\hline & Somateria fisheri & & & & & $\mathrm{E}$ & Laridae & Stercorarius longicaudus & $\mathrm{E}$ & $\mathrm{E}$ & $\mathrm{C}$ & & $\mathrm{E}$ \\
\hline & Somateria spectabilis & A & & A & & A & & Stercorarius parasiticus & & E & $\mathrm{E}$ & & \\
\hline & Polysticta stelleri & & & $\mathrm{E}$ & & $\mathrm{E}$ & & Stercorarius pomarinus & & & $\mathrm{C}$ & & E \\
\hline & Clangula hyemalis & & $\mathrm{E}$ & $\mathrm{E}$ & $\mathrm{C}$ & A & & Larus hyperboreus & $\mathrm{F}$ & $\mathrm{F}$ & $\mathrm{C}$ & A & A \\
\hline & Aythya marila & & & & & $\mathrm{E}$ & & Larus argentatus & $\mathrm{F}$ & $\mathrm{C}$ & $\mathrm{C}$ & A & A \\
\hline & Anas acuta & & $\mathrm{F}$ & A & & A & & Larus schistisagus & $\mathrm{E}$ & & $\mathrm{E}$ & & $\mathrm{E}$ \\
\hline & Mergus serrator & & & $\mathrm{E}$ & & & & Rissa tridactyla & $\mathrm{C}$ & & $\mathrm{C}$ & & \\
\hline & & & & & & & & Rissa brevirostris & $\mathrm{E}$ & & & & \\
\hline \multirow[t]{5}{*}{ Gaviidae } & Gavia arctica & & E & & & & & Sterna paradisaea & & & $\mathrm{C}$ & $\mathrm{F}$ & E \\
\hline & Gavia pacifica & & E & & & $\mathrm{E}$ & & & & & & & \\
\hline & Gavia stellata & & $\mathrm{E}$ & $\mathrm{E}$ & $\mathrm{E}$ & & Alcidae & Cepphus grylle & & & & & $\mathrm{E}$ \\
\hline & Gavia adamsii & & $\mathrm{F}$ & $\mathrm{F}$ & & $\mathrm{E}$ & & Cepphus columba & $\mathrm{C}$ & & $\mathrm{E}$ & & \\
\hline & & & & & & & & Uria lomvia & $\mathrm{C}$ & & $\mathrm{C}$ & & \\
\hline \multirow[t]{3}{*}{ Procellaridae } & Fulmarus glacialis & $\mathrm{F}$ & & & & & & Aethia cristatella & & & $\mathrm{E}$ & & \\
\hline & Puffinus tenuirostris & $\mathrm{C}$ & & & & & & Brachyramphus brevirostris & E & & & & \\
\hline & & & & & & & & Brachyramphus marmoratus & $\mathrm{E}$ & & & & \\
\hline \multirow[t]{2}{*}{ Phalacrocora } & Phalacrocorax pelagicus & $\mathrm{C}$ & A & & & $\mathrm{C}$ & & Synthliboramphus antiquus & $\mathrm{E}$ & & & & \\
\hline & & & & & & & & Fratercula cirrhata & $\mathrm{C}$ & & $\mathrm{C}$ & & \\
\hline \multirow[t]{3}{*}{ Falconidae } & Falco rusticolus & & $\mathrm{E}$ & E & & & & Fratercula corniculata & $\mathrm{C}$ & & $\mathrm{F}$ & & \\
\hline & Falco peregrinus & & $\mathrm{E}$ & & & E & & & & & & & \\
\hline & & & & & & & Strigidae & Nyctea scandiaca & & & & $\mathrm{E}$ & $\mathrm{F}$ \\
\hline \multirow[t]{2}{*}{ Phasianidae } & Lagopus lagopus & & $\mathrm{E}$ & & & & & & & & & & \\
\hline & & & & & & & Motacillidae & Anthus rubescens & $\mathrm{F}$ & E & & E & $\mathrm{E}$ \\
\hline \multirow[t]{2}{*}{ Gruidae } & Grus canadensis & $\mathrm{E}$ & $\mathrm{F}$ & $\mathrm{C}$ & & & & Anthus cervinus & E & E & $\mathrm{E}$ & & \\
\hline & & & & & & & & Motacilla alba & $\mathrm{E}$ & & & & $\mathrm{E}$ \\
\hline \multirow[t]{5}{*}{ Charadriidae } & Pluvialis squatarola & & & & $\mathrm{C}$ & & & Motacilla flava & $\mathrm{C}$ & A & E & & \\
\hline & Pluvialis apricaria & & $\mathrm{E}$ & & & & & & & & & & \\
\hline & Charadrius hiaticula & & $\mathrm{C}$ & $\mathrm{F}$ & $\mathrm{E}$ & & Turdidae & Luscinia svecica & & $\mathrm{E}$ & & & \\
\hline & Charadrius semipalmatus & & & & & $\mathrm{E}$ & & Oenanthe oenanthe & $\mathrm{E}$ & E & & & \\
\hline & & & & & & & & Ixoreus naevius & & & & & $\mathrm{E}$ \\
\hline \multirow[t]{11}{*}{ Scolopacidae } & Arenaria interpres & & & E & A & $\mathrm{C}$ & & & & & & & \\
\hline & Arenaria melanocephalus & & & E & & & Corvidae & Corvus corax & $\mathrm{E}$ & E & & & \\
\hline & Calidris ptilocnemis & & & E & & & & & & & & & \\
\hline & Calidris canutus & & & $\mathrm{F}$ & & A & Fringillidae & Carduelis flammea & & $\mathrm{F}$ & $\mathrm{F}$ & & E \\
\hline & Calidris alba & & & $\mathrm{E}$ & & $\mathrm{E}$ & & Carduelis hornemanni & $\mathrm{F}$ & $\mathrm{F}$ & $\mathrm{F}$ & & $\mathrm{C}$ \\
\hline & Calidris alpina & & $\mathrm{C}$ & A & A & $\mathrm{C}$ & & & & & & & \\
\hline & Calidris pusilla & & $\mathrm{E}$ & $\mathrm{E}$ & & A & Emberizidae & Calcarius lapponicus & $\mathrm{C}$ & $\mathrm{C}$ & A & $\mathrm{F}$ & A \\
\hline & Calidris mauri & & $\mathrm{A}$ & $\mathrm{A}$ & & $\mathrm{A}$ & & Plectrophenax nivalis & $\mathrm{F}$ & & $\mathrm{C}$ & $\mathrm{E}$ & $\mathrm{C}$ \\
\hline & Calidris bairdii & & & & & $\mathrm{E}$ & & Passerculus sandwichensis & & & & & $\mathrm{C}$ \\
\hline & Calidris temminckii & & $\mathrm{C}$ & & & & & & & & & & \\
\hline & Calidris ruficollis & & $\mathrm{C}$ & A & & & Passeridae & Passer montanus & $\mathrm{E}$ & & & & \\
\hline
\end{tabular}

${ }^{1} \mathrm{~A}=$ abundant,$>50$ individuals $; \mathrm{C}=$ common, $>10$ individuals; $\mathrm{F}=$ frequent, $>5$ individuals $; \mathrm{E}=$ encountered, at least 1 individual observed during counts on visit.

${ }^{2}$ Site 1 = Providenya; 2 = Mekigney Bay; 3 = along Chukchi coast, close to Cape Jinretlen; 4 = Wrangel Island; 5 = Barrow.

\section{ACKNOWLEDGEMENTS}

We are very grateful to meteorologist Bertil Larsson for all support and collaboration before, during, and after the expedition; to C.-G. Carlsson and Ulf Olsson at Aerotech-Telub for technical service and advice concerning the radar equipment; and to Catherine Mulligan for valuable electronic help and support of our radar work onboard Oden. Guy Morrison, Nils Warnock, and an anonymous referee provided constructive comments on the manuscript. We also wish to thank the Swedish Polar Research Secretariat and the crew of Oden, from which we received full support during the entire expedition. The project was financed by grants from the Swedish Research Council. Anders Hedenström is a Royal Swedish Academy of Sciences Research Fellow, supported by a grant from the Knut and Alice Wallenberg Foundation. 


\section{REFERENCES}

Alerstam, T., and Gudmundsson, G.A. 1999a. Migration patterns of tundra birds: Tracking radar observations along the Northeast Passage. Arctic 52(4):346-371.

- 1999b. Bird orientation at high latitudes: Flight routes between Siberia and North America across the Arctic Ocean. Proceedings of the Royal Society of London, B266:24992505.

Alerstam, T., and Pettersson, S.G. 1991. Orientation along great circles by migrating birds using a sun compass. Journal of Theoretical Biology 152:191-202.

Alerstam, T., Bauer, C.-A., and Roos, G. 1974. Spring migration of eiders Somateria mollissima in southern Scandinavia. Ibis 116:194-210.

Alerstam, T., Hjort, C., Högstedt, G., Jönsson, P.E., Karlsson, J., and Larsson, B. 1986. Spring migration of birds across the Greenland Inlandice. Meddelelser on Grønland, Bioscience 21. 38 p.

Alerstam, T., Gudmundsson, G.A., Green, M., and Hedenström, A. 2001. Migration along orthodromic sun compass routes by Arctic birds. Science 291:300-303.

Alerstam, T., Bäckman, J., Gudmundsson, G.A., Hedenström, A., Henningsson, S.S., Karlsson, H., Rosén, M., and Strandberg, R. 2007. A polar system of intercontinental bird migration. Proceedings of the Royal Society B 274:2523-2530.

Alerstam, T., Bäckman, J., Strandberg, R., Gudmundsson, G.A., Hedenström, A., Henningsson, S.S., Karlsson, H., and Rosén, M. 2008. Great-circle migration of arctic passerines. Auk 125(4):831-838, doi:10.1525/auk.2008.07142.

Batschelet, E. 1981. Circular statistics in biology. New York: Academic Press.

Flock, W.L. 1972. Radar observations of bird migration at Cape Prince of Wales. Arctic 25(2):83-98.

- 1973. Radar observations of bird movements along the Arctic coast of Alaska. Wilson Bulletin 85:259-275.

Gibson, D.D. 1977. First North American nest and eggs of the ruff. Western Birds 8:25-26.

Gill, R.E., Jr., and Handel, C.M. 1990. The importance of subarctic intertidal habitats to shorebirds: A study of the central YukonKuskokwim delta, Alaska. Condor 92:709-725.

Gill, R.E., Jr., Piersma, T., Hufford, G., Servranckx, R., and Riegen, A. 2005. Crossing the ultimate ecological barrier: Evidence for an 11 000-km-long nonstop flight from Alaska to New Zealand and eastern Australia by bar-tailed godwits. Condor 107:1-20.

Gudmundsson, G.A., and Alerstam, T. 1998. Why is there no transpolar bird migration? Journal of Avian Biology 29:9396.

Gudmundsson, G.A., Alerstam, T., Green, M., and Hedenström, A. 2002. Radar observations of Arctic bird migration at the Northwest Passage, Canada. Arctic 55(1):21-43.

Hedenström, A., and Alerstam, T. 1995. Optimal flight speed of birds. Philosophical Transactions of the Royal Society, London B 348:471-487.

Hedenström, A., Alerstam, T., Green, M., and Gudmundsson, G.A. 2002. Adaptive variation of airspeed in relation to wind, altitude and climb rate by migrating birds in the Arctic. Behavioural Ecology and Sociobiology 52:308-317.
Henningsson, S., and Alerstam, T. 2005. Patterns and determinants of shorebird species richness in the circumpolar Arctic. Journal of Biogeography 32:383-396.

Hoffecker, J.F., and Elias, S.A. 2003.Environment and archeology in Beringia. Evolutionary Anthropology 12:34-49.

Holmes, R.T., and Pitelka, F.A. 1998. Pectoral sandpiper (Calidris melanotos). In: Poole, A., and Gill, F., eds. The birds of North America, No. 348. Philadelphia, Pennsylvania: The Birds of North America, Inc.

Hultén, E. 1937. Outline of the history of Arctic and boreal biota during the Quarternary period. Stockholm: Bokförlags Aktiebolaget Thule.

Hupp, J.W., Schmutz, J.A., Ely, C.R., Syroechkovskiy, E.E., Jr., Kondratyev, A.V., Eldridge, W.D., and Lappo, E. 2007. Moult migration of emperor geese Chen canagica between Alaska and Russia. Journal of Avian Biology 38(4):462-470, doi:10.1111/ j.0908-8857.2007.03969.x.

Johnson, S.R., and Richardson, W.J. 1982. Waterbird migration near the Yukon and Alaskan coast of the Beaufort Sea: II. Moult migration of seaducks in summer. Arctic 35(2):291 - 301.

Karlsson, J. 1976. Flyghöjden hos ejder Somateria mollissima under vårflyttningen över sydligaste Skåne - bestämning med hjälp av radar. Fauna \& Flora 71:151-157.

Lehman, P.E. 2005. Fall bird migration at Gambell, St. Lawrence Island, Alaska. Western Birds 36:2-55.

Liechti, F., Hedenström, A., and Alerstam, T. 1994. Effects of sidewinds on optimal flight speed of birds. Journal of Theoretical Ecology 170:219-225.

Moreau, R.E. 1972. The Palaearctic-African bird migration systems. London: Academic Press.

Morrison, R.I.G. 1984. Migration systems of some new world shorebirds. In: Burger, J., and Olla, B.L., eds. Behavior of marine animals, Vol. 6. New York: Plenum Press. 125-202.

Parkes, K.C., and Amadon, D. 1948. The winter range of the Kennicott willow warbler. Condor 50:86-87.

Pennycuick, C.J. 1978. Fifteen testable predictions about bird flight. Oikos 30:165-176.

Richardson, W.J. 1979. Southeastward shorebird migration over Nova Scotia and New Brunswick in autumn: A radar study. Canadian Journal of Zoology 57:107-124.

Richardson, W.J., and Johnson, S.R. 1981. Waterbird migration near the Yukon and Alaskan coast of the Beaufort Sea: I. Timing, routes and numbers in spring. Arctic 34(2):108-121.

Rickberg, S., ed. 2006. Swedish Polar Research Secretariat. Yearbook 2005. Stockholm: Polarforskningssekretariatet.

Shamoun-Baranes, J., Van Loon, E., Liechti, F., and Bouten, W. 2007. Analyzing the effect of wind on flight: Pitfalls and solutions. Journal of Experimental Biology 210:82-90.

Thompson, M. 1973. Migratory patterns of ruddy turnstones in the central Pacific region. Living Bird 12:5-23.

Wilson, W.H. 1994. Western sandpiper (Calidris mauri). In: Poole, A., and Gill, F., eds. The birds of North America, No. 90. Philadelphia, Pennsylvania: The Birds of North America, Inc.

Winker, K., Gibson, D.D., Sowls, A.L., Lawhead, B.E., Martin, P.D., Hoberg, E.P., and Causey, D. 2002. The birds of St. Matthew Island, Bering Sea. Wilson Bulletin 114:491 - 509. 